\title{
Pengembangan instrumen tes untuk mengukur Higher Order Thinking Skills (HOTS) berorientasi Programme for International Student Asessment (PISA) pada peserta didik
}

\author{
Riza Umami, M. Rusdi, Kamid \\ Program Studi Magister Pendidikan Matematika, Universitas Jambi, Indonesia \\ E-mail: rizaumamisma0@gmail.com
}

\begin{abstract}
ABSTRAK
Pengembangan Instrumen merupakan suatu proses perancangan dan perakitan alat ukur agar menjadi alat ukur yang berkualitas baik. Tujuan penelitian ini untuk mengembangkan produk Instrumen Tes untuk mengukur Higher Order Thinking Skills (HOTS) berorientasi Programme for International Student Assesment (PISA) pada Peserta Didik yang berkategori layak digunakan. Produk yang dihasilkan meliputi dimensi kognitif, yakni instrumen tes essai berupa butir soal HOTS berorientasi PISA yang mencakup C4, C5, dan C6 dalam taxonomi Anderson dan Kartwohl dan dimensi afektif dan psikomotor berupa kemampuan berpikir kritis dan kemampuan berpikir kreatif. Penelitian ini merupakan Research and Development (R\&D) menggunakan langkah pengembangan dari ADDIE yang dikembangkan oleh Dick dan Carry (1996) yang diadopsi oleh Mulyatiningsih yang mencakup 5 langkah, yakni Analisis, Desain Pengembangan, Pelaksanaan Pengembangan, Penerapan dan Evaluasi. Berdasarkan hasil validasi produk oleh ahli, dihasilkan instrumen tes untuk mengukur Higher Order Thinking Skills (HOTS) berorientasi Programme for International Student Assesment (PISA) pada Peserta Didik. Dari hasil analisis yang dilakukan terhadap siswa mengenai instrumen ini, diperoleh 50\% dan menunjukkan kategori "sangat kompeten".
\end{abstract}

Kata Kunci: Research and Development (R\&D); instrumen tes; Higher Order Thinking Skills (HOTS); Programme for International Student Assesment (PISA).

\begin{abstract}
Instrument development is a process of designing and assembling measuring instruments to become good quality measuring instruments. The purpose of this research is to develop a test instrument product to measure Higher Order Thinking Skills (HOTS) oriented oriented Programme for International Student Assesment (PISA) for students who are categorized as suitable to be used. The product that reselted includes cognitive domain that is essay test instrument they are some problems HOTS oriented PISA that includes C4, C5 and C6 in Anderson and Kartwohl taxonomy also affective and psychomotoric dimentions with critical thinking skills and creative thinking skills. This research is research and development (R\&D) using development steps of ADDIE and developed by Dick and Carry (1996) which adapted by Mulyatiningsih It consists of 5 steps. The steps are Analysis, Design, Development, Implementation, and Evaluation. Based the result of validation by lecturers, to measure Higher Order Thinking Skills (HOTS) oriented Programme for International Student Assesment (PISA) of the students. From the results of the analysis carried out on students regarding this instrument, it was obtained 50\% and showed the category "very competent".
\end{abstract}


Keywords: Research and Development (R\&D); test instrument; Higher Order

Thinking Skills (HOTS); Programme for International Student Assesment (PISA).

\section{PENDAHULUAN}

Dalam Kurikulum 2013 terdapat dua aspek. Aspek pertama yang berisi merencanakan tujuan, isi, dan bahan ajar, aspek kedua berisikan proses dalam pembelajaran. Pada kurikulum ini juga menggunakan pendekatan tematik, yaitu terdapat beberapa kompetensi dari berbagai mata pelajaran yang dicantumkan dalam tema dan subtema. Kurikulum 2013 bertujuan untuk meningkatkan rasa ingin tahu dan mendorong peserta didik untuk lebih aktif dan kreatif dalam pembelajaran. Dalam sistem pembelajaran ada tiga komponen yang saling berhubungan dan tidak dapat dipisahkan. Komponen tersebut adalah tujuan dari pembelajaran itu sendiri, proses pelaksanaan dan penilaian pembelajaran. Tujuan pembelajaran dibuat dalam arahan pada kegiatan pembelajaran dan proses penilaian. Pada kegiatan belajar mengajar, penilaian adalah suatu hal yang penting, sebab dengan adanya menilai proses belajar pada peserta didik dapat mengetahui tercapai atau tidaknya tujuan pembelajaran yang telah dirumuskan dan diinginkan dalam standar kriteria ketuntasan minimal (KKM). Dengan adanya sistem penilaian ini tenaga pendidik bisa tahu seberapa efesiensikah teknik yang digunakan dalam proses pembelajaran.

Penilaian yang terdapat dalam kurikulum 2013 ada beberapa perubahan, berawal dari tes yang hanya mengukur kemampuan berpikir (kognitif) berdasarkan hasil saja, hingga pada penilaian autentik yang mengukur pada penilaian sikap, keterampilan dan pengetahuan (kognitif) berdasarkan proses dan hasil. Dalam penilaian autentik peserta didik diminta untuk menerapkan konsep yang diterapkannya pada dunia nyata. Pada Permendikbud No. 66 Tahun 2013 tentang standar penilaian dijelaskan bahwa penilaian adalah proses pencarian dan pengolahan informasi untuk menentukan pencapaian hasil belajar peserta didik. Maka dari itu, penilaian merupakan salah satu bagian yang paling penting dalam suatu proses belajar mengajar untuk pencapaian hasil belajar peserta didik.

Pada Kurikulum 2013 mempertegas materi dalam pembelajaran di setiap sekolah bahwa peserta didik memiliki kemampuan untuk mengestimasi, merencanakan, dan mempekirakan. Beriring jalan dengan itu ranah dari Higher Order Thinking Skills (HOTS) yaitu analisis yang merupakan kemampuan berpikir dalam mengkhususkan aspek-aspek tertentu; Evaluasi atau mempertimbangkan merupakan kemampuan berpikir dalam mengambil keputusan berdasarkan hal yang berkaitan dengan dunia nyata; dan mengkreasi merupakan kemampuan berpikir dalam membangun wawasan luas yang dimiliki oleh peserta didik tersebut. Jadi peserta didik di arahkan untuk belajar lebih aktif dan berkemampuan berpikir tingkat tinggi (Higher Order Thinking Skils/HOTS). Laporan yang telah didapatkan dengan data rendahnya kemampuan peserta didik Indonesia dalam hasil survey yang dilaksanakan oleh Benchmarking Internasional seperti PISA dan TIMSS memberi gambaran bahwa peserta didik dalam belajar berpikir kritis dan kreatif tidak langsung seperti belajar tentang materi, tetapi belajar bagaimana cara berpikir kritis dan kreatif dalam cara memproses untuk memecahkan masalah secara berkesinambungan. Contohnya menyelesaikan soal-soal PISA (Programme for International Student Assesment) yang terdapat dalam kehidupan sehari-sehari. Di sekolah untuk mengenal soal-soal HOTS berorientasi PISA sangatlah minim. Jika pun ada belum semaksimal mungkin peserta didik menguasainya. Maka dari itu peneliti mengembangkan soal-soal HOTS berorientasi PISA ini dengan tujuan agar peserta didik dapat berpikir tingkat tinggi dan kreatif dalam menguasai soal-soalnya. Peserta didik pun dapat berwawasan luas dalam mengerjakan soal-soal tersebut. Adapun tujuan dari penelitian ini adalah untuk meningkatkan kemampuan dari 
peserta didik tersebut, sampai sejauh mana kah peserta didik bisa berpikir tingkat tinggi dan berpikir kreatif dalam mengerjakan soal-soal HOTS berorientasi PISA ini.

Penilaian merupakan suatu proses mengumpulkan data melalui pengukuran, menafsirkan, mendeskripsikan, dan menginterpretasikan berdasarkan fakta yang sudah ada dari hasil pengukuran (kemendikbud, 2013). Penilaian memiliki peranan penting dalam pembelajaran, yaitu penilaian untuk pembelajaran (assessment for learning) dan penilaian sebagai pembelajaran (assessment as learning). Penilaian untuk pembelajaran (assessment for learning) memiliki manfaat dalam pengembangan untuk kemampuan yang akan dinilai. Hal tersebut pada awalnya berada pada rangkaian sasaran yang dituju bermakna saat pelaksanaan dan setelah pelaksanaan penilaian tersebut dilaksanakan. Penilaian di sisi lain juga sebagai assessment for learning (untuk pembelajaran), penilaian bahkan dapat berperan sebagai assessment as learning (sebagai pembelajaran), yaitu dapat berupa beberapa latihan-latihan yang dikerjakan oleh peserta didik, hingga mereka dapat banyak pembelajaran dari hal yang membuat mereka belum sepenuhnya yang didapat oleh mereka, serta belajar untuk mengendalikan dirinya, sehingga dapat menjadi pembelajaran yang baik. Pada tujuan assessment as learning, peserta didik diharapkan dapat menjadi pembelajar mandiri agar lebih dapat memuaskan hasil yang mereka dapat.

Penilaian hasil belajar peserta didik pada jenjang Sekolah Dasar dan Sekolah Menengah didasarkan pada ketentuan-ketentuan berikut (kemendikbud, 2013): (1) Valid, yaitu penilaian didasarkan pada data yang akan diambil dari kemampuan yang diukur, (2) Objektif, yaitu penilaian didasarkan pada cara dan ketentuan yang jelas, tidak dipengaruhi subjektivitas penilaian, (3) Adil, yaitu penilaian tidak menguntungkan atau merugikan peserta didik karena berkebutuhan khusus serta perbedaan latar belakang agama, suku, budaya, adat istiadat, status sosial, ekonomi dan gender, (4) Terpadu, yaitu penilaian merupakan salah satu elemen yang tidak dapat dipisahkan dari kegiatan pembelajaran, (5) Terbuka, yaitu tata cara penilaian, kriteria penilaian, dan dasar pengambilan keputusan dapat diketahui oleh pihak yang berkepanjangan, (6) Menyeluruh dan berkesinambungan, yaitu penilaian oleh guru mencakup semua aspek kompetensi yang digunakan berbagai cara oleh peserta didik, (7) Sistematis, yaitu penilaian dilakukan secara terencana dan bertahap dengan mengikuti langkah-langkah yang telah ditentukan, (8) Beracuan kriteria, yaitu penilaian didasarkan pada ukuran pencapaian kompetensi yang diterapkan, dan (10) Akuntabel, yaitu penilaian dapat dipertanggungjawabkan, baik dari segi teknik, prosedur, maupun hasilnya.

Instrumen adalah sarana penelitian (berupa seperangkat tes dan sebagainya) untuk mengumpul-kan data sebagai bahan pengolahan untuk mengukur suatu obyek ukur atau mengumpulkan data mengenai suatu variabel. Di dunia pendidikan, instrumen digunakan untuk mengukur prestasi belajar peserta didik, hal-hal yang diduga mempunyai hubungan terhadap hasil belajar, perkembangannya, tanda kesukseskan proses kegiatan belajar mengajar, dan keberhasilan pencapaian suatu program tertentu. Instrumen terdiri dari dua jenis, yakni instrumen tes dan instrumen non tes. Tes merupakan prosedur yang digunakan untuk mengetahui atau mengukur sesuatu dalam suasana dengan cara dan aturan-aturan yang sudah ditentukan.

Berdasarkan fungsinya, tes dikelompokkan dalam 5 jenis, sebagai berikut: (a) Tes Awal (Pre-Test): Bertujuan untuk mengetahui kemampuan peserta didik dalam menguasai materi pelajaran yang telah disampaikan oleh pendidik; (b) Tes Akhir (Post-Test): Bertujuan untuk mengetahui kemampuan peserta didik akan materi yang telah dikuasai; (c) Tes Penempatan (Placement Test): Tes penempatan ini dilakukan pada saat peserta didik pertama memasuki tahun ajaran baru untuk melihat seberapa besar kemampuan dari 
masing-masing peserta didik dalam menguasai materi pelajaran yang berhubungan dengan materi pembelajaran yang akan di ajarkan (ketika memasuki materi baru) dan diperuntukkan bagi peserta didik yang akan ditempatkan pada kelompok tertentu. Tes yang digunakan adalah tes dalam ruang lingkup luas dan tingkat kesukarannya bermacammacam; (d) Formatif (Formative Tes): Tes ini dilakukan ketika pembelajaran sedang berlangsung yang bertujuan untuk mengetahui perkembangan pembelajaran peserta didik untuk menilai apakah guru berhasil atau tidak. Tes formatif biasanya mengacu pada kriteria tertentu yaitu tercapainya tujuan, sedangkan pada tes penempatan mengacu pada norma tertentu yaitu norma kelompok; (e) Diagnostik (Diagnostic Test): Tes ini bertujuan untuk memeriksa kesulitan belajar peserta didik. Dikarenakan memeriksa kesulitan belajar, maka tes ini dilaksanakan diawal guna untuk mengetahui sampai mana peserta didik menguasai materi yang bersangkutan; (f) Sumatif (Summative Test): Tes sumatif dilakukan pada akhir pokok pembelajarn baik pada akhir semester hingga bisa pada akhir tahun ajaran pada program tertentu.

Keterampilan berpikir tingkat tinggi (Higher Order Thinking Skill/HOTS) yaitu cara atau teknik peserta didik dengan menggunakan kemampuan untuk menganalisis, merencanakan, mendesain, mengimplementasikan dan mengevaluasi segala permasalahan yang ada. Menurut Uno (2012), soal HOTS memiliki empat indikator, yaitu: (1) Proses dalam menemukan masalah dan cara memecahkan masalah berdasarkan informasi yang nyata, sehingga dapat ditarik kesimpulan; (2) Keterampilan pengambilan keputusan, yaitu keterampilan seseorang dalam memecahkan masalah melalui pengumpulan informasi/data untuk dapat mengambil keputusan terbaik dalam memecahkan masalah; (3) Keterampilan berpikir kritis adalah usaha untuk mencari informasi yang akurat/lebih terpercaya yang digunakan sebagaimana mestinya pada suatu masalah; dan (4) Keterampilan berpikir kreatif, artinya menghasilkan banyak ide, berwawasan luas hingga memunculkan dobrakan/keputusan yang belum pernah ada untuk memecahkan masalah.

Menurut Taksonomi Bloom yang telah ada perubahan dalam kemampuan berpikir tingkat tinggi yang terdapat didalamnya menganalisis $\left(\mathrm{C}_{4}\right)$, mengevaluasi $\left(\mathrm{C}_{5}\right)$, dan mencipta $\left(\mathrm{C}_{6}\right)$ dianggap berpikir tingkat tinggi (Krathworl \& Anderson, 2010). Anderson telah melakukan penelitian serta didapatkan perbaikan dalam Taksonomi Bloom yang sudah ada. Perbaikan tersebut yakni mengubah Taksonomi Bloom dari kata benda menjadi kata kerja. Hal ini dilakukan karena Taksonomi Bloom yang sebenarnya yaitu menggambarkan proses berpikir, setelah itu dilakukanlah pergeseran susunan taksonomi bloom yang menjabarkan berpikir tingkat rendah ke berpikir tingkat tinggi.

Pada Taksonomi Bloom terjadi perubahan dalam pengembangannya ke dalam Taksonomi Anderson dan Krathwohl, yaitu berawal dari satu dimensi menjadi dua dimensi antara lain, Dimensi Pengetahuan (Knowledge Dimension) dan Dimensi Proses Kognitif (Cognitive Process Dimension). Dimensi proses kognisi terdapat 6 kategori, yaitu kemampuan mengingat, memahami, dan menerapkan yang merupakan kemampuan berpikir tingkat rendah. Selain itu kemampuan menganalisis, mengevaluasi, dan mencipta termasuk kemampuan berpikir tingkat tinggi. Kategori-kategori dalam dimensi proses kognitif menurut revisi Taksonomi Bloom (Krathwohl, D dan Anderson, L, 2010): Mengingat (C1): Pada kategori ini, peserta didik dilihat terlebih dahulu dan memiliki dasar pemikiran dalam memori mengenai pembelajaran dasar sebelumnya sebelum ke jenjang kategori selanjutnya, dikarenakan kategori mengingat ini bertujuan dalam pembelajarannya adalah menumbuhkan kemampuan untuk meretensi materi pelajaran sama seperti materi yang diajarkan, kategori proses kognitif yang tepat adalah Mengingat. Proses mengingat adalah mengambil pengetahuan yang dibutuhkan dari memori jangka panjang dan sangat diperlukan. Pengetahuan yang dibutuhkan ini boleh jadi Pengetahuan Faktual, Konseptual, 
Prosedural, atau Metakognitif, atau kombinasi dari beberapa pengetahuan ini; Memahami (C2): Memahami yaitu menafsirkan sebuah pengetahuan awal yang dimiliki, sebelum terkontaminasi oleh pengetahuan-pengetahuan lainnya mengaitkan informasi yang baru dengan pengetahuan yang telah dimiliki, atau mengintegrasikan pengetahuan yang baru atau belum dikenal sama sekali ke dalam skema yang telah ada dalam pemikiran pesertas didik. Peserta didik dikatakan memahami ketika mereka mampu untuk membangun makna dari pesan instruksional termasuk lisan, tertulis, dan grafis komunikasi, dan materi yang disampaikan. Proses kognitif dalam kategori Memahami termasuk mencontohkan (examplifying), mengklasifikasi (classifying), meringkas (summarizing), menyimpulkan (inferring), membandingkan (comparing), dan menjelaskan (explaining); Mengaplikasikan (C3): Kategori aplikasi atau penerapan bertujuan untuk menerapkan aktivitas-aktivitas yang dilakukan pada peserta didik dalam proses pembelajaran. Pada kategori ini dibagi lagi menjadi dua bagian atau komponen yaitu proses eksekusi dan proses mengimplementasikan pada tugas-tugas yang sedang berjalan dan yang belum berajalan dalam artian belum pernah ditemukan oleh peserta didik sama sekali mengenai proses studinya; Menganalisis (C4): Menganalisa merupakan menjabarkan suatu permasalahan ke bentuk penyusunnya dan menentukan bagaimana saling berkaitan satu sama lain. Kategori ini meliputi proses kognitif membedakan, pengorganisasian, dan atributing. Kemampuan untuk membedakan dapat diasesmenkan dengan soal soal jawaban singkat atau pilihan ganda. Dalam soal jawaban singkat peserta didik diberikan sebuah kalimat dan diminta untuk menunjukan bagian mana yang paling penting atau relevan. Mengorganisasi adalah proses kognitif yang melibatkan proses mengidentifikasi situasi dan proses mengenali bagaimana elemen ini membentuk sebuah struktur yang berkesinambungan. Dalam mengorganisasi siswa dituntut untuk membangun hubungan yang sistematis dan koheren antar potongan informasi; Mengevaluasi (C5) Dapat diartikan sebagai pertimbangan atau penilaian berdasarkan kriteria dan standar yang ada. Kriteria yang sering dipakai adalah kualitas, efektifitas, efisiensi, dan konsistensi. Standar mengevaluasi dapat berbentuk kuantitatif. Mengevaluasi termasuk juga proses kognitif memeriksa dan mengkritisi. Standar ini bisa dipergunakan juga untuk pendidik dan peserta didik. Pada tahap evaluasi, siswa harus mampu membuat penilaian dan keputusan tentang nilai suatu metode, gagasan, atau benda dengan menggunakan kriteria yang telah ditetapkan tingkatan ini mencakup dua aspek kognitif, yaitu memeriksa (checking) dan mengkritik (critiquing). Contoh kata kerja operasional yang digunakan pada jenjang evaluasi adalah menilai, membandingkan, mengkritik, membela, menjelaskan, menafsirkan, membenarkan, menyimpulkan, dan mendukung; Menciptakan (C6): Mengkreasikan maksud dari kategori ini adalah menempatkan komponen secara bersama untuk membuat satu kesatuan yang utuh yakni menyusun ulang ke dalam struktur/susunan yang baru. Bagian yang termasuk dalam kategori ini adalah hipotesa, rencana, dan memproduksi. Untuk merumuskan kategori "menciptakan" ini, pendidik diusulkan untuk tidak terlalu sering menggunakan assesmen pilihan ganda. Dalam merencanakan, siswa bisa jadi menentukan sub-sub tujuan, atau merinci tugas menjadi sub-sub tugas yang harus dilaksanakan ketika menyelesaikan masalah.

Pada tahun 2003, studi yang dilakukan oleh Programme for International Student Assessment (PISA) menunjukkan prestasi Indonesia pada urutan 36 dari 41 negara. Pada tahun 2006, skor perolehan peserta didik pada matematika menetap hanya pada angka 391 (skala 0-800), padahal rata- rata skor sebesar 500. Hasil PISA tahun 2009 Indonesia di peringkat 61 dari 65 negara peserta dengan nilai rata-rata hanya 371 dan PISA terakhir tahun 2012 posisi Indonesia berada pada peringkat 64 dari 65 negara dengan skor 375. Untuk informasi lebih lanjut dapat dilihat pada grafik dibawah ini. 


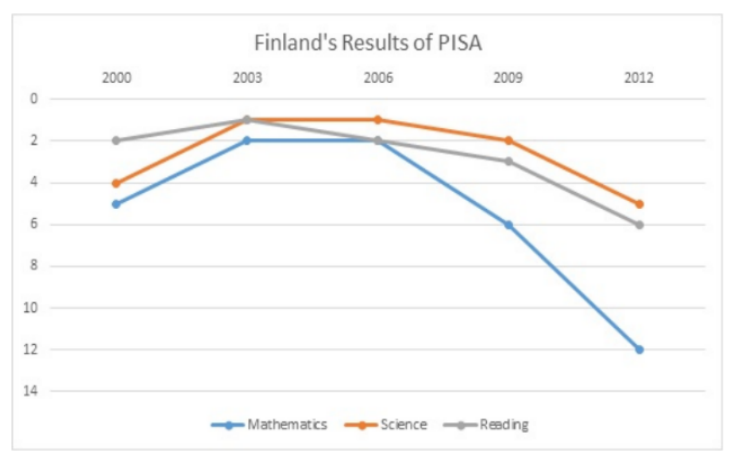

Grafik Hasil PISA Indonesia (OECD, 2013)

PISA singkatan dari Programme for International Student Assessment yang merupakan sebuah proyek dari Organisation for Economic Co-operation and Development (OECD) yang dirancang untuk mengevaluasi atau menilai hasil pendidikan dalam hal kemampuan peserta didik yang berumur 15 tahun di bidang matematika, membaca, dan sains.

Pada program PISA terdapat struktur matematika yang berpola sebagai berikut: ML + 3 Cs. ML adalah singkatan dari Mathematical Literacy (literasi matematika), dan 3 Cs singkatan dari konten (Content), konteks (Contexts), dan kompetensi (Competencies). Misalkan adanya suatu persoalan mengenai situasi dan kondisi dalam dunia nyata, situasi dan kondisi ini menyediakan konteks untuk diimplementasikan dalam matematika. Untuk menggunakan matematika dalam memecahkan masalah, seorang siswa harus memiliki tingkat kemampuan yang meliputi konten matematika yang relevan dengan masalah tersebut agar lebih mudah mengatasi persoalan yang ada. Untuk menyelesaikan masalah tersebut, proses untuk menghasilkan solusi harus dibangun, diikuti, dan diteliti. Agar penggunaan proses ini berhasil, seorang siswa membutuhkan kompetensi tertentu, yang dibahas dalam Competency cluster di framework PISA. Hubungan bentuk matematika: ML + 3 Cs dari PISA tersebut dapat dilihat pada skema sebagai berikut:

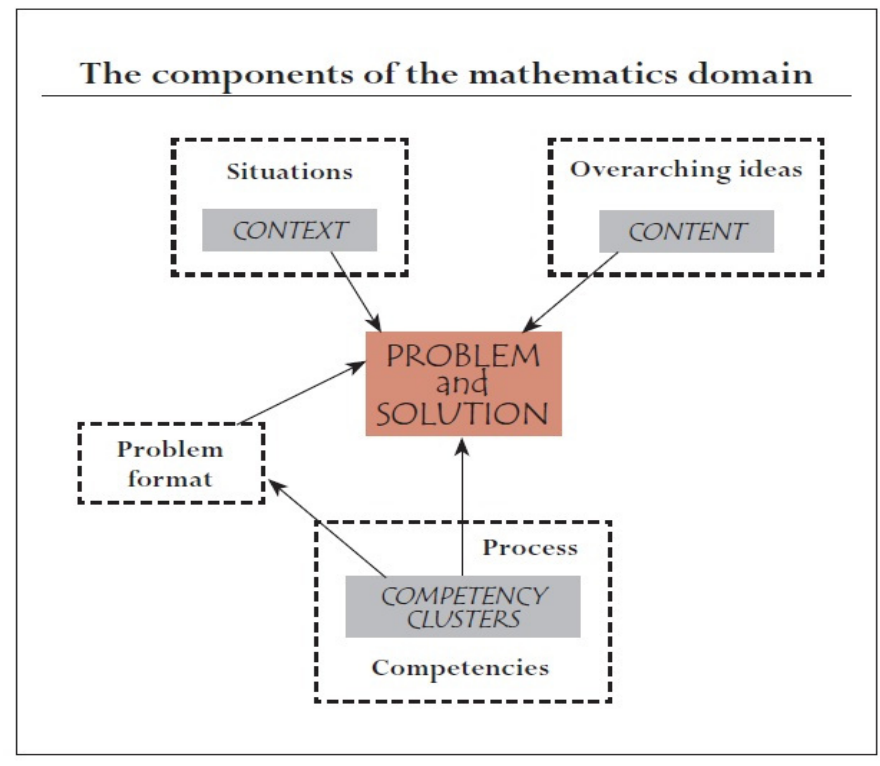

Komponen Matematika PISA

Source: OECD (2009) Learning Mathematics for Life: A View Perpective from PISA, OECD Publications, Paris. 
Untuk membuat, dan menerbitkan butir- butir soal Higher Order Thinking Skills (HOTS) yang berorientasi Programme for International Student Assessment (PISA) haruslah mengandung komponen-komponen yang terkait pada HOTS dan PISA tersebut, seperti konten PISA meliputi perubahan dan hubungan (change and relationships), ruang dan bentuk (space and shape), bilangan (quantity) dan probabilitas/ketidakpastian dan data (uncertainty and data). Konteks PISA meliputi konteks pribadi (personal), konteks pekerjaan (occupational), konteks umum (societal), dan konteks keilmuan (scientific). Komponen proses meliputi komponen proses reproduksi (reproduction cluster), komponen proses koneksi (connection cluster), komponen proses refleksi, (reflection cluster). Serta levelnya memiliki hingga 6 level. Itulah kandungan untuk membuat butir-butir soal HOTS berorientasi PISA selain terdapat C4, C5, dan C6.

Berikut adalah beberapa contoh soal PISA yang telah dikembangkan yang terinspirasi dari soal yang sudah ada.

\section{SOAL PISA}

\section{Menu Rumah Makan}

Content : Uncertainty
Context $\quad$ : Personal
Competency: Connection

Dibawah ini adalah daftar menu makanan pada Rumah Makan TOP MIX:

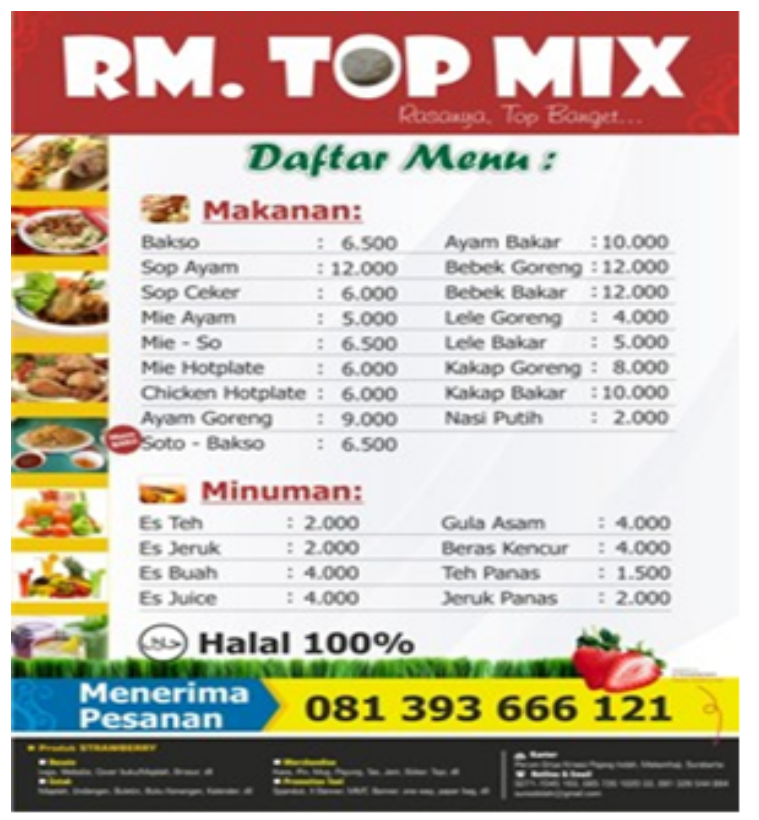

Pembeli ingin memesan satu makanan dan satu minuman dari menu di atas, tetapi dia hanya memiliki uang sebesar Rp 15.000,00. Tentukan banyak pilihan pasangan makanan dan minuman yang dapat dipilih (Contoh satu pasangan adalah mie ayam dan es juice, atau sop ceker dan es jeruk, dll).

Jelaskan jawabanmu! 
Rubrik Penilaian Hasil Kerja Siswa Menyelesaikan Soal PISA

Pedoman Rubrik Penilaian Hasil Kerja Siswa

\begin{tabular}{|c|c|c|c|c|}
\hline Aspek Analisis & Skala 4 & Skala 3 & Skala 2 & Skala 1 \\
\hline $\begin{array}{l}\text { Ketepatan } \\
\text { penggunaan } \\
\text { konsep } \\
\text { matematika }\end{array}$ & $\begin{array}{l}\text { Penggunaan } \\
\text { konsep } \\
\text { matematika tepat } \\
\text { dan sesuai } \\
\text { dengan } \\
\text { keseluruhan } \\
\text { permasalahan } \\
\text { pada soal }\end{array}$ & $\begin{array}{l}\text { Penggunaan } \\
\text { konsep } \\
\text { matematika } \\
\text { tepat, namun } \\
\text { kurang sesuai } \\
\text { dengan sebagian } \\
\text { kecil } \\
\text { permasalahan } \\
\text { pada soal }\end{array}$ & $\begin{array}{l}\text { Penggunaan } \\
\text { konsep } \\
\text { matematika } \\
\text { kurang tepat, } \\
\text { namun sesuai } \\
\text { dengan } \\
\text { permasalahan } \\
\text { pada soal }\end{array}$ & $\begin{array}{l}\text { Penggunaan } \\
\text { konsep } \\
\text { matematika } \\
\text { kurang tepat dan } \\
\text { tidak sesuai } \\
\text { dengan } \\
\text { permasalahan } \\
\text { pada soal }\end{array}$ \\
\hline $\begin{array}{l}\text { Ketepatan } \\
\text { perhitungan }\end{array}$ & $\begin{array}{l}\text { Seluruh jawaban } \\
\text { benar, rinci, dan } \\
\text { terurut }\end{array}$ & $\begin{array}{l}\text { Seluruh jawaban } \\
\text { benar, namun } \\
\text { tidak rinci dan } \\
\text { tidak terurut }\end{array}$ & $\begin{array}{l}\text { Sebagian besar } \\
\text { jawaban benar, } \\
\text { namun kurang } \\
\text { rinci dan tidak } \\
\text { terurut }\end{array}$ & $\begin{array}{l}\text { Sebagian kecil } \\
\text { jawaban benar, } \\
\text { kurang rinci dan } \\
\text { tidak terurut }\end{array}$ \\
\hline $\begin{array}{l}\text { Mengidentifikasi } \\
\text { langkah-langkah } \\
\text { dalam } \\
\text { menyelesaikan } \\
\text { permasalahan } \\
\text { pada soal }\end{array}$ & $\begin{array}{l}\text { Mampu } \\
\text { mengidentifikasi } \\
\text { dengan tepat } \\
\text { setiap langkah } \\
\text { penyelesaian } \\
\text { permasalahan } \\
\text { pada soal }\end{array}$ & $\begin{array}{l}\text { Mampu } \\
\text { mengidentifikasi } \\
\text { dengan tepat } \\
\text { sebagian besar } \\
\text { langkah } \\
\text { penyelesaian } \\
\text { permasalahan } \\
\text { pada soal }\end{array}$ & $\begin{array}{l}\text { Mampu } \\
\text { mengidentifikasi } \\
\text { dengan tepat } \\
\text { sebagian kecil } \\
\text { langkah } \\
\text { penyelesaian } \\
\text { permasalahan } \\
\text { pada soal }\end{array}$ & $\begin{array}{l}\text { Hanya } \\
\text { mengidentifikasi } \\
\text { diketahui atau } \\
\text { ditanya atau } \\
\text { sebagian proses } \\
\text { penyelesaian atau } \\
\text { hanya hasil akhir } \\
\text { saja }\end{array}$ \\
\hline $\begin{array}{l}\text { Mengemukakan } \\
\text { alasan atau } \\
\text { gagasan }\end{array}$ & $\begin{array}{l}\text { Menuliskan } \\
\text { semua alasan } \\
\text { atau gagasan dari } \\
\text { awal langkah- } \\
\text { langkah } \\
\text { penyelesaian soal } \\
\text { sampai akhir }\end{array}$ & $\begin{array}{l}\text { Menuliskan } \\
\text { sebagian besar } \\
\text { alasan atau } \\
\text { gagasan dari } \\
\text { langkah-langkah } \\
\text { penyelesaian soal }\end{array}$ & $\begin{array}{l}\text { Menuliskan } \\
\text { sebagian kecil } \\
\text { alasan atau } \\
\text { gagasan dari } \\
\text { langkah-langkah } \\
\text { penyelesaian soal }\end{array}$ & $\begin{array}{l}\text { Tidak menuliskan } \\
\text { alasan atau } \\
\text { gagasan dari } \\
\text { langkah-langkah } \\
\text { penyelesaian soal, } \\
\text { atau hanya } \\
\text { menuliskan } \\
\text { gagasan akhir } \\
\text { secara singkat }\end{array}$ \\
\hline
\end{tabular}

\section{METODE PENELITIAN}

Pada penelitian ini, peneliti memilih jenis penelitian pengembangan (Research and Development). Bertujuan agar produk yang telah dikembangkan dapat membantu para pendidik agar lebih mudah untuk menilai hasil kerja peserta didik dalam proses belajar mengajar. Desain pengembangan yang digunakan dalam penelitian ini adalah model pengembangan ADDIE yang dikembangkan oleh Dick dan Carry (1996). Model pengembangan ADDIE secara garis besar terdiri dari lima fase, yaitu, Analisis (Analysis), Desain Pengembangan (Design), Pelaksanaan Pengembangan (Development or Production), Implementasi atau penerapan (Implementation or Delivery), dan Evaluasi (Evaluations) / (ADDIE). Alasan peneliti memilih model ADDIE dalam penelitian pengembangan ini adalah model ini merupakan model prosedural, yaitu model yang bersikap deskriptif, menunjukkan langkah-langkah yang jelas dan cermat untuk menghasilkan produk, kemudian tahap-tahap pengembangan dalam model ini sama dengan standar tahap pengembangan dan alasan terakhir adalah model ADDIE telah digunakan secara luas dan terbukti dapat memberikan hasil yang baik. Jadi peneliti dengan mudah dan merasa terbantu dalam menyelesaikan peneliti ini. 
Desain pengembangan ini mengadaptasi model pengembangan ADDIE. Namun dengan tidak mengurangi validitas proses dan temuan dalam penelitian ini secara garis besar penelitian ini hanya terdiri dari lima tahap utama yaitu analisis (analysis), desain pengembangan (design), pelaksanaan pengembangan (development), Penerapan (implementasi) dan Evaluasi (evaluasi). Pada tahap analisis dilakukan analisis pendahuluan yang terdiri dari analisis kebutuhan dan studi literatur. Pada tahap desain pengembangan terdiri dari jadwal pengembangan, tim pengembangan, spesifikasi desain instrumen pengembangan. Untuk tahap pengembangan terdiri dari validasi dari ahli guna mengetahui kevalidan dan kepraktisan produk tersebut, revisi produk dan dilakukan evaluasi produk yang dikembangkan.

Pada analisis data kuantitatif dari hasil soal tes HOTS berorientasi PISA dengan menggunakan pedoman penskoran instrumen tes berikut.

Keterangan Skala penilaian :

$\begin{array}{ll}\text { Sangat kompeten } & =4 \\ \text { Kompeten } & =3 \\ \text { Cukup kompeten } & =2 \\ \text { Kurang kompeten } & =1 \\ & \\ \text { Jumlah aspek penilaian } & =10 \\ \text { Skor maksimum } & =40 \\ \text { Skor minimum } & =10\end{array}$

$\%$ Nilai Tes $=\frac{\text { Jumlah } \text { Skor }}{\text { Skor Maksimum }} \times 100 \%=\frac{\text { Jumlah } \text { Skor }}{40} \times 100 \%=\ldots$

Keterangan : Jumlah skor maksimum dari soal tes disesuaikan dengan jumlah butir soal yang dinilai.

Misal: aspek yang dinilai berjumlah 16 komponen maka perhitungan untuk nilai tes adalah jumlah skor dibagi skor maksimumnya lalu dikalikan 100\% dimana skor maksimum untuk 16 aspek penilaian adalah 64, begitu seterusnya.

Tabel 2. Pedoman Penskoran Instrumen Tes

\begin{tabular}{llll}
\hline No & Skor siswa & \% nilai KPS siswa & Kategori KPS \\
\hline 1 & $31-40$ & $76 \%-100 \%$ & Sangat kompeten \\
2 & $21-30$ & $51 \%-75 \%$ & Kompeten \\
3 & $11-20$ & $26 \%-50 \%$ & Cukup kompeten \\
4 & 10 & $25 \%$ & Kurang kompeten \\
\hline
\end{tabular}

\section{HASIL DAN PEMBAHASAN}

Hasil penelitian ini berdasarkan pada hasil uji dari instrumen tes yang telah dibuat oleh peneliti yang diterapkan pada siswa Sekolah Dasar (SD). Setelah melalui proses penelitian dan pengembangan yang tahapannya meliputi Analysis, Design, Development, Implementation dan Evalution (Mulyatiningsih, 2012). Dalam hal ini peneliti membuat desain intrumen tes ini mengacu kepada materi HOTS yang berorientasi PISA. Sistem penilaian yang dilakukan oleh guru matematika salah satu Sekolah Dasar Kota Jambi dalam penilaian pembelajaran telah mencakup aspek kognitif, afektif, dan psikomotorik (Munandar, 2002). Alat ukur atau sistem yang digunakan sekolah salah satunya menggunakan instrumen tes. Instrumen tes merupakan sarana penelitian (berupa 
seperangkat tes dan sebagainya) untuk mengumpul-kan data sebagai bahan pengolahan mengukur sesuatu dalam suasana dengan cara dan aturan-aturan yang sudah ditentukan. Seiring jalan dengan itu ranah dari HOTS yaitu analisis yang merupakan kemampuan berpikir dalam menggunakan aspek-aspek/elemen dari sebuah konteks tertentu; evaluasi merupakan kemampuan berpikir dalam mengambil keputusan berdasarkan fakta/informasi; dan mengkreasi merupakan kemampuan berpikir dalam membangun wawasan yang luas dan dituntut untuk berpikir kritis dalam memecahkan masalah. Maka dari itu peserta didik untuk belajar lebih aktif dan berkemampuan berpikir tingkat tinggi dan dapat menyelesaikan soal-soal PISA yang terdapat dalam kehidupan sehari-hari.

Pada penelitian ini, untuk mengetahui efektifitas dari pengembangan instrumen tes ini peneliti mengadakan wawancara secara ringkas pada peserta didik dan guru matematika. Dari hasil penelitian ada beberapa penjelasan dan harapan bahwa nantinya instrumen ini akan berguna kelak dalam proses pembelajaran terutama untuk pesertas didik dikelas. Praktikalitas setuju dengan adanya instrumen tes ini karena sebelumnya mereka jarang bahkan tidak pernah menggunakannya dalam membahas soal-soal yang lebih luas, melainkan hanya menggunakan soal-soal umum sekitar mata pelajaran yang ada. Pada pertemuan pertama peneliti mendapat masukan dari guru di sekolah, mengatakan bahwa sejauh ini guru-guru disekolah baru merencanakan ingin memberi peserta didik soal-soal yang berbau HOTS saja, tidak sespesific soal yang diajukan peneliti hingga berorientasi PISA. Soal-soal umum saja yang sering kali mereka bahas disekolah. sehingga wawasan peserta didik hanya berputar sekitar itu saja tidak meluas, peserta didik pun seharusnya bisa mengeluarkan semua yang ada dalam pikirannya tetapi tidak bisa apresiasikan, itu sangat disayangkan sekali. Maka dari itulah guru-guru matematika di sekolah tersebut merasa terbantu sehingga instrumen tes ini dapat digunakan di sekolah ini dengan tujuan untuk dapat mengeksplore atau menjelajahi kemampuan berpikir peserta didik dan instrumen yang telah dikembangkan sudah bisa dikatakan valid dan efektif. Jadi dapat membantu peserta didik juga untuk lebih mengenal soal-soal level tinggi.

Instrumen tes dikatakan bisa digunakan atau layak, kemudian diimplementasikan pada tujuan penelitian, yakni peserta didik Sekolah Dasar di Kota Jambi dan guru praktikalitasnya, mengikuti proses penelitian peneliti sebanyak 10 peserta didik. Implementasi ini dilakukan sebanyak 2 kali pertemuan. Untuk itu peserta didik dituntut untuk aktif dan kreatif dalam pelaksanaan kegiatan belajar mengajar sedangkan pendidik hanya sebagai fasilitator serta membantu dan hanya mengarahkan peserta didik dalam belajar. Untuk mengetahui seberapa besar keaktifan dan kreatif peserta didik dalam mengikuti pembelajaran. maka diadakan pengamatan. Hasil pengamatan dari proses belajar menunjukkan bahwa instrumen tes ini sudah efektif untuk meningkatkan aktivitas belajar peserta didik.

Dari sepuluh soal tersebut yang telah diberikan kepada 10 peserta didik, dapat terjawab dengan kemampuan mereka masing-masing. Jawaban mereka hampir sama, namun masih bisa diketahui perbedaannya. Dari 10 peserta didik, ada yang menjawab soal secara berurutan, rapi, kreatif, cermat, dan bisa dikatakan bisa menjawab dengan langkah-langkah yang menurut mereka bisa memuaskan mereka. Maksudnya memuaskan bagi mereka adalah mereka dapat berkreatifitas mulai dari proses belajarnya hingga dalam menjawab sepuluh soal dari peneliti dengan menggunakan caranya sendiri walaupun tidak banyak. Untuk menjawab soal dari peneliti, peserta didik diperbolehkan mengapresiasikan pikiran mereka seluas-luasnya. Mereka bisa lebih mengespos kemampuan masing-masing tanpa dibimbing guru. Guru hanya sebagai fasilitator. Ada peserta didik yang menjawab soal seperti biasa yaitu hanya menggunakan rumus kemudian dijabarkan tanpa harus berpikir kreatif bagaimana cara untuk menjawab soal tersebut akan bisa berbeda dengan 
menggunakan caranya sendiri. Dalam penelitian ini tidak luput dengan adanya kemampuan menganalisis suatu pekerjaan mereka dan urut-urutan, kecepatan mengerjakan tugas, membaca gambar atau simbol, serta keserasian hasil jawaban yang diharapkan. Penilaian telah dilakukan dalam dua hari, kemudian dianalisis oleh peneliti bersama guru disekolah untuk mendapatkan dan mengetahui hasil HOTS berorientasi PISA dari masing-masing peserta didik tersebut dan melihat berapa besarkah persentasi dari pengaruh instrumen tes ini terhadap peserta didik yang diambil dalam kelompok kecil yaitu sebanyak 10 orang karena diambil dari skor mereka yang tertinggi. Dari hasil analisis, didapatkan 50\% dengan kategori "Sangat Kompeten". Sebagaimana dipaparkan sebagai berikut: Siswa 1 dengan jumlah skor 29 memiliki persentase nilai 72,5\% ; Siswa 2 dengan jumlah skor 30 memiliki persentase nilai 75\% ; Siswa 3 dengan jumlah skor 35 memiliki persentase nilai 87,5\% ; Siswa 4 dengan jumlah skor 26 memiliki persentase nilai 65\% ; Siswa 5 dengan jumlah skor 34 memiliki persentase nilai 85\% ; Siswa 6 dengan jumlah skor 34 memiliki persentase nilai 85\% ; Siswa 7 dengan jumlah skor 33 memiliki persentase nilai 82,5\% ; Siswa 8 dengan jumlah skor 25 memiliki persentase nilai $62,5 \%$; Siswa 9 dengan jumlah skor 30 memiliki persentase nilai 75\%; dan Siswa 10 dengan jumlah skor 34 memiliki persentase nilai $85 \%$ . Dari 10 siswa ini diketahui mendapat kategori "Sangat Kompeten" dengan rentang persentase (\%) yaitu 76\%-100\% dan kategori "Kompeten" dengan rentang persentase (\%) yaitu $51 \%-75 \%$.

\section{SIMPULAN DAN SARAN}

Secara garis besar penelitian ini terdiri dari lima tahap utama yaitu analisis (analysis), desain pengembangan (design), pelaksanaan pengembangan (development), implementasi (implementation), dan evaluasi (evaluation). Pada akhirnya menghasilkan produk yakni instrumen tes HOTS berorientasi PISA pada peserta didik yang telah diambil pada saat penelitian berlangsung. Produk ini divalidasi oleh ahli dan dilakukan revisi terhadap hasil validasi ahli tersebut. Kemudian produk hasil revisi ahli yaitu instrumen tes HOTS berorientasi PISA pada peserta didik ini di lihat oleh guru dan beri banyak saran untuk kesempurnaan instrumen, untuk soal tes akan diberikan pada siswa. Hasil validasi pertama oleh ahli untuk instrumen tes terdapat empat komponen yang divalidasi oleh ahli yakni soal yang akan di terapkan pada instrumen, deskripsi komponen kriteria penilaian/deskriptor pencapaian, komponen instrumen tes, dan deskripsi pemberian skor penilaian. Semua komponen tersebut peneliti revisi berdasarkan saran dari ahli. Kemudian hasil validasi kedua oleh ahli untuk instrumen tes terdapat lima komponen yang divalidasi oleh ahli yakni susunan instrumen, kata-kata yang bersifat teknik pada instrumen skor skala penilaian, komponen aspek penilaian, dan deskripsi bobot kriteria penilaian. Semua komponen yang divalidasi oleh ahli peneliti lakukan revisi sesuai saran sehingga diperoleh komentarkomentar yang positif tentang instrumen tes HOTS berorientasi PISA pada peserta didik tersebut.

Untuk validasi aspek praktikalitas yang dilakukan oleh guru matematika sebagai validator, sebagian besar memberikan respon yang positif terhadap semua produk. Komentarkomentar dari guru tersebut berkenaan dengan penggunaan dan manfaat produk. Guru yang memberikan saran agar pengembangan instrumen tes disesuaikan dengan materi. Setelah dilakukan uji coba terbatas untuk intrumen tes tersebut $50 \%$ siswa mendapatkan kategori "sangat baik". 


\section{DAFTAR RUJUKAN}

Anderson, L dan Krathwohl, D. (2010). Kerangka Landasan Untuk Pembelajaran, Pengajaran dan Asesmen Revisi Taksonomi Pendidikan Bloom. Yogyakarta : Pustaka Pelajar.

Budiman,Agus."Pengembangan Instrumen Asesmen Higher Order Thinking Skill (HOTS) Pada Mata Pelajaran SMP Kelas VIII Semester 1."Jurnal Riset Pendidikan Matematika1, no. 2 (2014): h. 2

Dimyati. dan Mudjiono. (2009). Belajar dan pembelajaran. Jakarta: Rineka Cipta.

Kementerian Pendidikan dan Kebudayaan. 2013. Implementasi Kurikulum 2013, (online), (http://www.slideshare.net/nayantakahusnahartono/sosialisasi-implementasikurikulum-2013.html. Diakses 28 Juli 2020).

Kementerian Pendidikan dan Kebudayaan. 2013. Pengembangan Kurikulum 2013: Paparan Menteri Pendidikan dan Kebudayaan RI, (online), (http://upi.edu/main/file/Paparan Mendikbud Sosialisasi Kurikulum 2013 Bandung 16 Maret 2013 Tayang.pptx. Diakses 28 Juli 2020).

Mulyatiningsih, endang. (2012). Metode Penelitian Terapan Bidang Pendidikan. Bandung, Indonesia: Alfabeta.

Munandar, Utami. (2002). Strategi Mewujudkan Potensi Kreatif \& Bakat. Jakarta, Indonesia: Gramedia Pustaka Utama.

Organisation for Economic Co-operation and Development. (2009). Learning Mathematics for Life: A View Perpective from PISA.Paris: OECD Publications.

Organisation for Economic Co-operation and Development. (2012). PISA 2012 Results: What Students Know and Can Do: OECD Publications.

Organisation for Economic Co-operation and Development. (2013).OECD Skills Outlook 2013: Fisrt Results From The Survei of Adult Skills: OECD Publications.

Ronda, Erlina. 2011. What is Mathematical Literacy, (online), (http: //math4teaching.com/2010/03/12/what-is-mathematical-literacy. Diakses 28 Juli 2020).

Sugiyono. (2009). Metode Penelitian Pendidikan pendekatan kuantitatif, kualitatif, dan R\&D. Bandung: CV. Alfabeta.

Uno, Hamzah B. Model Pembelajaran Menciptakan Proses Belajar Mengajar yang Kreatif dan Efektif. Jakarta: PT Bumi Aksara 2012. 